Gut, 1972, 13, 387-389

\title{
The effect of lymphocytes from sufferers from recurrent aphthous ulceration upon colon cells in tissue culture
}

\author{
A. E. DOLBY
}

From the Welsh National School of Medicine, University of Wales, Dental School, Heath, Cardiff

SUMmARY The release of ${ }^{51} \mathrm{Cr}$ from labelled colon cells was used to assess a possible lymphocytotoxic effect of peripheral blood lymphocytes from patients suffering from recurrent aphthous ulceration. No significant $(\mathrm{P}>0.03)$ difference was observed between the isotope release following incubation with patients' or control lymphocytes. The absence of such a lymphocytotoxic effect, detectable with oral epithelial cells, is discussed in relation to the role of cellular hypersensitivity in the pathogenesis of ulcerative colitis and aphthous ulceration.

It has been suggested that cellular hypersensitivity may be of significance in the aetiology of Mikulicz's recurrent oral aphthae (Graykowski, Barile, Boyd Lee, and Stanley, 1966; Lehner, 1967). Furthermore, it has recently been shown that peripheral blood lymphocytes obtained from patients suffering from this disorder are cytotoxic for oral epithelial cells in tissue culture (Dolby, 1969).

This phenomenon of lymphocytotoxicity has previously been demonstrated in relation to ulcerative colitis, employing lymphocytes from patients with this disease and colon as the source of target cells (Perlmann and Broberger, 1963). A further similarity exists in the immunopathology of ulcerative colitis and Mikulicz's recurrent oral aphthae. Thus, raised titres of haemagglutinating antibodies to foetal colon antigen have been detected in patients suffering from ulcerative colitis (Broberger and Perlmann, 1962) and to foetal oral mucosa antigen in patients suffering from Mikulicz's recurrent oral aphthae (Lehner, 1964). Immunization with bacterial antigen which crossreacts with tissue antigen has been suggested as the explanation for the presence of the antibodies in both ulcerative colitis (Broberger and Perlmann, 1962; Lagercrantz, Hammarström, Perlmann, and Gustafsson, 1968) and recurrent oral aphthae (Kramer, 1965). Oral ulceration may recur during the stage of symptoms in ulcerative colitis and will respond to topical corticosteroid therapy (Truelove and Morris-Owen, 1958) a treatment which is effective in Mikulicz's recurrent oral aphthae (Cooke and Armitage, 1960). The immuno-

Received for publication 6 March 1972. logical and clinical association between these two diseases led to the choice, in this investigation, of colon cells as targets in initial attempts to determine the specificity of the lymphocyte cytotoxicity in Mikulicz's recurrent oral aphthae.

\section{Patients, Materials, and Methods}

SOURCE AND PREPARATION OF LYMPHOCYTES The donors of lymphocytes consisted of patients suffering from recurrent aphthous ulceration (four female, two male; age range 22-56) and six persons, matched for sex and age, who did not suffer from this disease. Lymphocytes from each of the patients suffering from recurrent aphthous ulceration had been shown previously to be cytotoxic for oral epithelial cells in vitro (Dolby, 1969; 1970). The lymphocytes were separated from the venous blood using the method previously described (Dolby, 1969).

PREPARATION AND LABELLING OF SUSPENSIONS OF COLONIC EPITHELIAL CELLS

Fresh specimens of colon were obtained from patients with carcinoma of the colon in whom resection was carried out. From the uninvolved portion of the specimen the mucosa was dissected free, cut into small fragments and trypsinized for approximately two and a half hours. The cells were then washed three times in tissue culture medium 199 (TC 199) and resuspended to a concentration of $2 \times 10^{5}$ cells per ml. Viability was estimated by Trypan blue exclusion and in each case exceeded $90 \%$. Since the colon cells appeared somewhat similar in appearance to lymphocytes it was decided to employ isotope 
release rather than visual examination for assessment of cytotoxic effect.

For labelling the colon cells with isotope $3 \mathrm{ml}$ of the suspension containing approximately $8 \times 10^{5}$ cells per ml was incubated for one hour at $37^{\circ} \mathrm{C}$ with 70 to 100 microcuries 51 chromium sodium chromate (specific activity 300 microcuries per micromol, Radiochemical Centre, Amersham). The colon cells were washed three times in ice-cold TC 199 and the activity of the final wash supernatant was recorded. Lymphoid cell suspensions $\left(1.5 \times 10^{6}\right.$ per $\mathrm{ml}$ ) from the donors were added to the colon cell suspensions $\left(3 \times 10^{5}\right.$ cells per $\left.\mathrm{ml}\right)$ and incubated for 24 hours at $37^{\circ} \mathrm{C}$ in $3.3 \mathrm{ml}$ of TC 199. Triplicate suspensions were used in each case. At $6,9,18$, and 24 hours the cell suspensions were centrifuged for 10 minutes at $200 \mathrm{~g}$ and $0.3 \mathrm{ml}$ of cell-free supernatant was removed. The isotope content of the supernatants and the final cell suspensions was measured in a Nuclear Chicago gamma counter. The results were expressed as the percentage isotope remaining in the cell suspensions after removal of each of the supernatants. Repeated freezing and thawing of the cell suspensions at the termination of the experiments was also undertaken and the radioactivity in these supernatants measured also.

\section{Results}

The percentage isotope remaining in the cell suspensions after removal of the supernatants is shown graphically in the Fig. each point representing the mean of three triplicate suspensions. There was no significant difference $(P>0.03)$ between the total radioactivity released where lymphocytes from aphthae patients had been added and where control lymphocytes had been added. The freezing and thawing of the cell suspensions resulted in supernatant radioactivity $(260 \pm 32 \mathrm{cpm} / \mathrm{ml})$ considerably

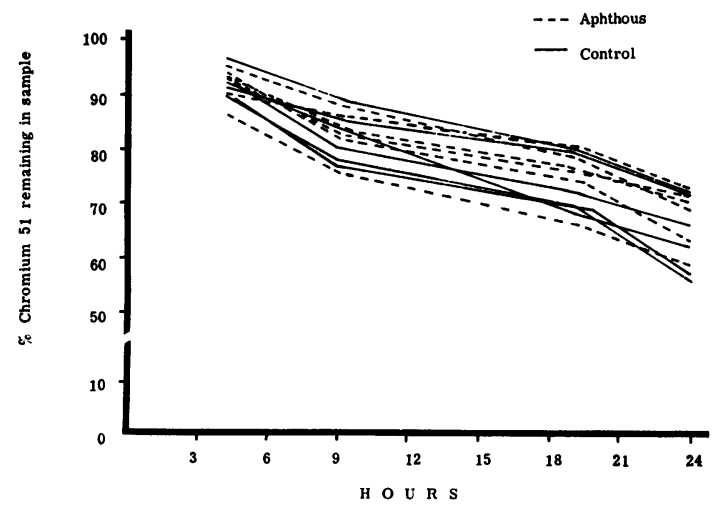

Fig. The percentage isotope remaining in the cell suspensions after removal of the supernatants. higher than that of the final preparatory washing $(70 \pm 48 \mathrm{cpm} / \mathrm{ml})$.

\section{Discussion}

Peripheral blood lymphocytes obtained from patients suffering from Mikulicz's recurrent oral aphthae appear, when compared with lymphocytes from control subjects, to be without cytotoxic effect upon colon cells. Although the lymphocyte/target cell ratio employed here was lower than that achieved in the investigation reported by Perlmann and Broberger (1963) it was similar to the ratio employed in the studies of Mikulicz's recurrent oral aphthae (Dolby, 1969; 1970). The labelling isotopes also differ, ${ }^{32} \mathrm{P}$ and ${ }^{14} \mathrm{C}$ Alga protein having been employed by Perlmann and Broberger (1963). However, ${ }^{51} \mathrm{Cr}$ has been widely used in assaying lymphocyte cytotoxicity and is thought to be accurate and reliable (Goodman, 1961; Rogentine and Plocinik, 1967; Wigzell, 1965; Holm and Perlmann, 1967; Brunner, Mauel, Cerottini, and Chapuis, 1968). The degree of labelling achieved in these experiments, revealed by the difference between the radioactivity of the final wash and that released by repeated freezing and thawing, would appear adequate for a target system. The radioisotope release measured is presumed to be representative of spontaneous release as well as of any lymphocyte/colon cell interaction which may have occurred.

Lymphocyte-mediated cell damage is thought to consist of at least two stages, contactual agglutination of lymphocytes with target cells followed by lysis of the target cells (Rosenau and Moon, 1961). The interaction of sensitized guinea-pig lymphocytes with antigen in vitro has been shown to result in the release of a soluble mediator capable of causing cell death (Dumonde, Wolstencroft, Panayi, Matthew, Morley, and Howson, 1969) in which the first stage only exhibits specificity. Thus, in these experiments it is possible that there is a failure of the lymphocytes from aphthae sufferers to recognize antigenic markers on the colon cells. The cells mediating cellular immunity are generally accepted to be thymic or thymus derived, and although the mechanism whereby these lymphocytes recognize antigen is not known, it would appear that sufficient similarity does not exist between these two groups of target cells, that is, colonic and oral, for antigen recognition to occur. This may reflect the difference in the antigens derived from oral and colon cells (saline-soluble and phenol/water-soluble respectively) in the humoral antibody detected in the experiments described above (Broberger and Perlmann, 1962; Lehner, 1964). It does not, however, 
preclude the possibility of oral epithelial attack by lymphocytes in ulcerative colitis, a phenomenon which may underly the oral ulceration sometimes accompanying this disease (Truelove and MorrisOwen, 1958).

I am grateful to Professor B. E. D. Cooke, Professor of Oral Medicine and Oral Pathology, and to Mr D. Crosby, consultant surgeon, United Cardiff Hospitals, for colon tissue. The work was supported by grants from the British Medical Association and the Board of Governors, The United Cardiff Hospitals.

\section{References}

Broberger, O., and Perlmann, P. (1962). Demonstration of an epithelial antigen in colon by means of fluorescent antibodies from children with ulcerative colitis. J. exp. Med., 115, 13-27.

Brunner, K. T., Mauel, J., Cerottini, J. C., and Chapuis, B. (1968) Quantitative assay of the lytic action of immune lymphoid cells on ${ }^{51} \mathrm{Cr}$-labelled allogeneic target cells in vitro: inhibition by isoantibody and by drugs. Immunology, 14, 181-196.

Cooke, B. E. D., and Armitage, P. (1960). Recurrent Mikulicz's aphthae treated with topical hydrocortisone hemisuccinate sodium. Brit. med. J., 1, 764-770.

Dolby, A. E. (1969). Recurrent aphthous ulceration: effect of sera and peripheral blood lymphocytes upon oral epithelial tissue culture cells. Immunology, 17, 709-714.

Dolby, A. E. (1970). Mikulicz's recurrent oral aphthae: the effect of anti-lymphocyte serum upon the in vitro cytotoxicity of lymphocytes from patients for oral epithelial cells. Clin. exp. Immunol., 7, 681-686.
Dumonde, D. C., Wolstencroft, R. A., Panayi, G. S., Matthew, M., Morley, J., and Howson, W. T. (1969). Lymphokines': Nonantibody mediators of cellular immunity generated by lymphocyte activations. Nature (Lond.), 224, 38-42.

Goodman, H. S. (1961). A general method for the quantitation of immune cytolysis. Nature (Lond.), 190, 269-270.

Graykowski, E. A., Barile, M. F., Boyd Lee, W., and Stanley, H. R., Jr. (1966). Recurrent aphthous stomatitis. Clinical, therapeutic, histopathologic and hypersensitivity aspects. J. Amer. med. Ass., 196, 637-644.

Holm, G., and Perlmann, P. (1967). Quantitative studies on phytohaemagglutinin-induced cytotoxicity by human lymphocytes against homologous cells in tissue culture. Immunology, 12 525-536.

Kramer, I. R. H. (1965). 'Aphthous' and herpetic lesions of the oral mucosa. Proc. roy. Soc. Med., 58, 458-462.

Lagercrantz, R., Hammarström, S., Perlmann, P., and Gustafsson, B. E. (1968). Immunological studies in ulcerative colitis. IV. Origin of autoantibodies. $J$. exp. Med., 128, 1339-1352.

Lehner, T. (1964). Recurrent aphthous ulceration and autoimmunity. Lancet, 2, 1154-1155.

Lehner, T. (1967). Stimulation of lymphocyte transformation by tissue homogenates in recurrent oral ulceration. Immunology, 13, 159-166.

Perlmann, P., and Broberger, O. (1963). In vitro studies of ulcerative colitis. II. Cytotoxic action of white blood cells from patients on human fetal colon cells. J. exp. Med., 117, 717-733.

Rogentine, G. N., Jr., and Plocinik, B. A. (1967). Application of the ${ }^{51} \mathrm{Cr}$ cytotoxicity technique to the analysis of human lymphocyte isoantigens. Transplantation, 5, 1323-1333.

Rosenau, W., and Moon, H. D. (1961). Lysis of homologous cells by sensitized lymphocytes in tissue culture. J. nat. Cancer. Inst., 27, 471-483.

Truelove, S. C., and Morris-Owen, R. M. (1958). Treatment of aphthous ulceration of the mouth. Brit. med. J., 1, 603-607.

Wigzell, H. (1965). Quantitative titrations of mouse $\mathbf{H}-2$ antibodies using $\mathrm{Cr}_{51}$ labelled target cells. Transplantation, 3, 423-431. 